\title{
STORYTELLING METHOD TO IMPROVE STUDENT'S VOCABULARY IN RA SEMBILAN BINTANG CITAYAM
}

\author{
Rr. Astri Indriana Octavita; Rima Novia Ulfa \\ Program of English Education, Faculty of Language and Art, University of Indraprasta PGRI \\ Jalan Nangka No. 58C Tanjung Barat, Jagakarsa, South Jakarta 12530 \\ mrs.astriindriana@gmail.com, rymanovia@gmail.com
}

\begin{abstract}
Vocabulary is an important component in teaching English in addition to other components such as structure, pronunciation and intonation. Vocabulary has a very significant role. If a student is weak in the habit of using vocabulary, then the student cannot communicate his thoughts and ideas as accurately as he wants both oral and written. The method of storytelling is a method for developing students' language skills, while the function of storytelling is to help the development of children's language skills, by adding vocabulary, saying words, training in composing sentences in accordance with the stage of development. The method of storytelling was chosen by the researchers to demonstrate it in front of RA Sembilan Bintang students, which is located in Citayam, West Java. The results of exposure to the classroom action research data point out that the teaching of vocabulary is quite effective and increasing student's language acquisition before and after the learning process significantly.
\end{abstract}

Keywords: PAUD students, vocabulary, storytelling, language

\section{ABSTRAK}

Kosakata adalah komponen penting dalam pengajaran bahasa Inggris di samping komponen lain seperti struktur, pengucapan dan intonasi. Kosakata memiliki peran yang sangat vital. Jika seorang siswa lemah dalam kebiasaan menggunakan kosakata, maka siswa tidak dapat mengkomunikasikan pikiran dan idenya secara akurat seperti yang ia inginkan baik lisan maupun tulisan. Metode mendongeng adalah metode untuk mengembangkan keterampilan bahasa anak-anak, sedangkan fungsi mendongeng adalah untuk membantu pengembangan keterampilan bahasa siswa, dengan menambahkan kosakata kosa kata, mengucapkan kata-kata, pelatihan menyusun kalimat sesuai dengan tahap perkembangannya. Metode mendongeng dipilih oleh para peneliti untuk mendemonstrasikannya di depan siswa RA Sembilan Bintang, yang berlokasi di Citayam, Jawa Barat. Hasil penelitian dengan penerapan penelitian tindakan kelas ini menunjukkan bahwa pengajaran kosakata dianggap sangat efektif dan dapat meningkatkan pemerolehan bahasa siswa sebelum dan setelah proses pembelajaran kosakata secara signifikan.

Kata Kunci: siswa PAUD, kosakata, mendongeng, bahasa 


\section{INTRODUCTION}

Education is not only obtained in the family environment, but also in the social environment of the community as well as from school. Understanding education in the school environment has a broader meaning than teaching. Teaching is more focused on the process of transforming affective knowledge. Education is a two-way communication process which is not only a process of transforming knowledge but also the process of internalizing character values. The character of each student is different and must be mastered by a teacher if the learning process of teaching in the classroom can be successful. It is the teacher's job to understand each student's character, because each student has a different way of understanding and mastering the material presented by the teacher.

"Early Childhood Education is an education organized to develop personal, knowledge, and skills that underlie basic education and develop themselves in full in accordance with the principles of education as early as possible and for life" (Suyanto, 2005:45). The aspects developed in Early Childhood Education are aspects of developing behavior with habituation which includes social, emotional, independence, moral and religious values as well as the development of basic abilities which include physical, motor, cognitive, and language development (Arikunto, dkk., 2009). Language is a very important communication tool. Humans in their lives cannot be separated from language as a communication tool. Language will make it easier for humans to get along, to communicate and to adjust themselves to the environment. Thus, it is clear that language has a very important role for humans (Suhartono, 2005).

Children's language develops from the first cry until the child speaks the words. The child's language development period is divided into two periods, namely the Pre-Linguistic period 0 until 1 year old, and the Linguistic period 1 year until 5 years old. During the Pre-Linguistic era, the child makes sounds and babbling that cannot be understood and understood. Whereas in the Linguistic period the child begins to speak one or two words that can already be understood and understood. If in this Linguistic period many children are given language stimulation, then the child's language development will be rapid and optimal (Musfiroh, 2005).

English is one of the languages from many languages in the world. English is an international language and the official language used by various countries around the world to communicate and to share it verbally both formally and informally. If someone is in another country, not in his own country, then the first communication tool used is English. Every country must know about English so it will ease a communication between individuals despite different ethnicities, races, nationalities and cultures. English can unite people in the world and all information and communication can be achieved with English, therefore English plays a very important role.

English in the world of education has long been held. English began to be taught to elementary, middle, high school and college students. The current position of English in the curriculum is not a main subject. Each school is given the authority to organize learning English or not. If you find a school that does not 
teach English and there are schools that teach English it is a different policy that is applied from each school.

Childhood is an important time to adjust to the environment for children's development and growth. Children have unique characteristics, because the children themselves have differences from one child with another. Early childhood education is a learning process using the principle of "Playing while learning or learning while playing" in accordance with the characteristics and aspects of early childhood development. One good learning method is to use the method of storytelling.

Musfiroh (2005:58) argues that "Storytelling is regarded as one of the appropriate methods of developing children's vocabulary to be applied in PAUD". One of the methods of storytelling is to develop children's language skills, while the function of storytelling is also to help the development of children's language skills by adding vocabulary, saying words, practicing sentence arrangement in accordance with the stages of their development. The effect of storytelling method is also a gift of learning experience.

In learning a foreign language, like English, learning English in PAUD or kindergarten places are more emphasized on the vocabulary learning. Vocabulary, which is taught at every different grade level. This is because vocabulary learning is adjusted to the characteristics of students and students' age so that students can achieve maximum learning. The vocabulary taught in early childhood English learning, such as students in PAUD, generally takes the form of an introduction to English vocabulary.

Meanwhile, Birch (2015) argues that poor readers avoid reading, and lack of reading practice means they do not improve. By reading, the vocabulary will increase. This proposition is also supported by Tierney \& Readence (2005) who state: "Without a doubt there exists a strong relationship between vocabulary knowledge and reading comprehension". In short, vocabulary building can be reached also by doing more reading practices.

At an early age language development is very important because early childhood is a sensitive period for children and English is an international language. Lately the government has launched an international standard education starting from the level of basic education to higher education. Learning delivered at international standard schools uses English instruction. This is done by the government as an effort to improve human resources who have reliability in English. Children need to master a foreign language, especially English; therefore, English is introduced from an early age, especially at Children's Education institutions early age. This is based on the assumption that children learn foreign languages faster than adults (Santrock, 2007).

Language acquisition requires a lot of vocabularies and adequate forms of grammar. Vocabulary mastery influences in making English sentences and in understanding English. Mastery of English vocabulary is important to teach at the age of elementary students because students can remember and understand more vocabulary. Vocabulary mastery will affect sentence making, content suitability and expected explanation in English. The mastery of English vocabulary also affects the conversation, grammar and tenses of English in the next level. Vocabulary mastery is the basis of the concept of understanding in English. 
In this research, the researcher took the place of research at PAUD Raudhatul Athfal Bintang, which is located in Citayam, which is under the auspices of the Ministry of Religion. This research is conducted to seek, to shape and to develop all the physical and psychological potentials and abilities of children by using learning methods in RA education, which are guided by program activities that have been prepared. Learning in PAUD must be presented by playing, playing with fun, and using interesting media. This is in accordance with the principles of learning in PAUD namely "playing while learning and learning while playing". Therefore, learning is made and designed so that children are interested in learning English. Play provides an element of fun and happiness in children. Playing provides opportunities for children to solve problems experienced. Playing is a way for children to imitate people and master adult behavior to reach maturity.

From the above background, it is clear that English needs to be taught early on and it should be delivered with interesting methods and media. Language is an important communication tool for humans. Humans think with their brains, but for others to know their intentions, these thoughts must be expressed. Language as a tool to express thoughts, feelings and desires for humans to others. Language also contributes greatly to the development of early childhood.

Early childhood grows and develops into an adult human who can mingle in the midst of society by using language. This is consistent with the opinion of Suhartono (2005:8) who states that "With the help of language, children grow from biological organisms become personal in the group". Furthermore, Suhartono
(2005:8) argues that "Language is a series of sounds that symbolize human thoughts, feelings, and attitudes".

In addition, according to Arikunto, dkk. (2009:65), "Children's language has a meaning that is the language used by children to convey desires, thoughts, hopes, requests, etc. for their personal interests". This proposition implies that language is a very important communication tool. To every student, especially in early childhood education, language learning must be given appropriately, so that the children are better to able to master the functions of the language. In fact, the language owned by an individual's experience development continuously in accordance with the age level.

Language is obtained from anywhere and can be learned. The first language that students recognize is a mother tongue. Students experience stages of development so that they are able to learn a second language. Anyone, especially children can have the ability to speak two or more languages with all. The person is said to have bilingualism. Lado in Suhartono (2005:102) states that "Bilingualism is the ability to speak two languages equally or nearly as well". Hence, bilingualism is the interchangeable use of two or more languages, through the use of two languages by a speaker or the community. In analyzing the learning of English, and the technique of storytelling, the researchers see that in this research a theory of listening must also be used.

The process of introducing a foreign language consists of several language components, which are parts of a language program. In general, the language component consists of three, namely: grammar, vocabulary, and pronunciation. This is in line with the statement from Suyanto (2005:43) who 
states that "Vocabulary is a collection of words owned by a language and gives meaning when we use the language". From some of the opinions mentioned above it can be concluded that vocabulary is a part of a sentence that is owned by someone. In general, children learn words or vocabulary faster when supported by visual aids, such as pictures or objects. Learning vocabulary and English grammar will be better if it is in the context related to the world of children, so it is easy to practice or to communicate.

\section{METHOD}

This research employs Classroom Action Research. The purpose of this study is to improve PAUD students' English vocabulary. This research leads to the natural field setting. The scope of research is very limited and action research is more aimed at making changes to all participants and changes in the situation of the research site. This was done to achieve continuous improvement in practice. The exposure of Classroom Action Research in this present research is carried out by through stages, namely: planning, implementing, reflecting collaborative and participatory actions with the aim of improving teacher performance, so that student learning outcomes can improve. The type of class research used is collaborative research. Suhardjono in Arikunto, dkk. (2009) argues that one of the distinctive features of Classroom Action Research is the collaboration or collaboration between teachers, principals, students and students' parents. The selection of partners in community service activities is based on the needs of teachers to improve their ability in mastering English and understanding the importance of
English, especially in the field of education.

\section{RESULTS AND DISCUSSION}

Analysis on increasing the mastery of English vocabulary through the use of storytelling techniques to students of PAUD RA Bintang Sembilan discusses the description of the situation and research location, the description of early stage observations, the research implementation and the observation of learning English in PAUD RA Bintang Sembilan. This observation is carried out to find a picture of the learning process before the research is carried out and to identify the problems that occur in the classroom during the learning process.

During the learning process, it appears that the teacher has not used the appropriate media in delivering the material. The teacher gives the meaning of words about the vocabulary taught verbally and students are randomly asked to answer questions from the teacher about the meaning of the word verbally as well. Students are asked to read a vocabulary that is listed in the package book at a glance and has not found an understanding for students. Students are not given the opportunity by the teacher to write vocabulary that has just been learned in their respective books during the learning process until the end of learning, so there is no student practicing a vocabulary.

Based on the preliminary observations made, it is known that students' mastery of English vocabulary is still low. This initial condition is supported by conducting an assessment of every aspect of English vocabulary mastery in the initial proficiency test. The average value of students in every aspect of mastering English vocabulary before taking action is as follows. For example, if students hear the word 
"Animal", the researchers will bring their thoughts, about the name of animals, such as: cat, duck and so on, which can be seen in the following chart:

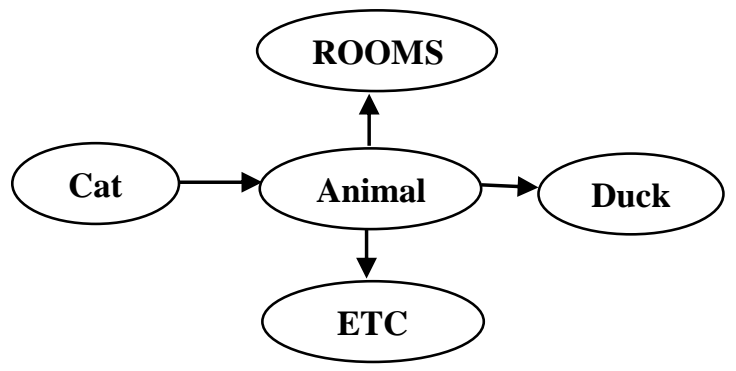

Figure 1

Vocabulary Assessment

Through story telling techniques like this, students will not be surprised that they are learning, but they are playing. English learning is easily absorbed by the child's brain and children's vocabulary improvement is also good. This is in accordance with the opinion of Vygotsky in Musfiroh (2005:14) who states that "Children need to play because it is in play that children firstly find knowledge in the social world which then becomes part of children thinking and solving problems". It is during playing that the child shows his ability everyday. It is that he is someone playing.

Play encourages children to engage in flexible thinking processes and creative problem solving processes. Because children focus on the play process, they play an active role in combining ideas and solutions they use to solve problems accordingly. Children construct knowledge, relate it to social contexts, and use their skills to solve problems. From this non-class research, the researchers get the results, the ability is a learning process that supports children's development.

The indicator of success in this study is to improve the ability of children to recognize English vocabulary seen during the learning process, as well as from an increase in the percentage of children's ability outcomes. The success of this class action assessment is marked by a change towards improvement. The success will be seen if the activities to recognize English vocabulary using the media of the flannel board have increased. The criterion for success in this study is if 80 percent from the number of children scored with good criteria.

In addition to be influenced by the strategy of playing pictures, the success of English learning is also influenced by supporting methods in the form of giving instructions on how to speak This supporting method also plays quite a lot because through this method can minimize problems and boredom experienced by children. This method of giving instructions can help children to more easily interpret the knowledge they get into the memory of their brain. The increase in each cycle does not show stability. While students are learning to know English vocabulary, the teacher and researcher observe and record the child's development, especially in the ability to recognize English vocabulary. Based on observations in learning, especially aspects of language knowing English vocabulary, it can be seen that learning is less done in a pleasant atmosphere.

In English according to the picture, it can be seen that some children take part in imitating utterances even though there is still the sound of incorrect pronunciation, and children have difficulty when saying BIRD (birds), most children say BIRD (birds). However, there were also children who played alone and did not participate in imitating utterances, so teachers must warn children to participate in imitating spoken English words according to what is said by researchers and teachers. 
In addition, it is not uncommon, children, who do not want to say the words according to the picture and do not listen to the teacher.

The application of the storytelling method is expected to succeed and to reach the level as expected and can improve the vocabulary ability through the method of storytelling, namely the type of child. The first type is students do not pay attention, so they do not remember the vocabulary given. Then, in the second type, the child has noticed and does not understand 1 to 2 given vocabulary. Then, there are also types of students who have noticed and understood 1 to 2 of the vocabulary given. In the next type, there are children who already understand 1 to 2 vocabulary given, but do not know the meaning. The last type is students who already understand 1 to 2 given vocabulary and understand its meaning.

The criterion of the results of this study, the success of using the storytelling method in improving the mastery of English vocabulary of children aged 3 to 6 years in PAUD RA Sembilan Bintang as follows:

1. The ability of children to recognize 20 written English vocabulary parts of the body, like spelling vocabulary from the name of animals.

2. The child's ability to pronounce correctly. The twentieth English vocabulary the name of animals, in pronouncing vocabulary from the name of animals.

3. The ability of children to understand twenty meanings of English vocabulary.

\section{CONCLUSION}

Based on the results of exposure to the classroom action research data conclusions can be drawn as follows:

1. The teaching of vocabulary through three stages of teaching that is applied in R.A Sembilan Bintang Citayam is quite effective and increasing student acquisition before and after the learning process is quite meaningful (significant).

2. Vocabulary learning through these three stages of teaching in R.A Sembilan Bintang Citayam progressed increasingly, after researchers gave the storytelling method.

3. Students should be involved in the learning process, which prioritizes the development of Student's vocabulary abilities.

Finally, the use of storytelling method is an effective learning method for learning English Early Childhood vocabulary. This is because playing pictures is a learning strategy that is in accordance with the principles of learning in early childhood, Moreover, by storytelling, those students do not feel that they are, indeed learning something. They think that they are playing. Through playing, children can build knowledge, can interact socially with friends, feel free without burdens and feel happy. This encourages children to actively participate in learning so as to improve English vocabulary of early childhood..

\section{REFERENCES}

Arikunto, S., dkk. (2009). Penelitian Tindakan Kelas. Jakarta: PT. Bumi Aksara.

Birch, M. B. (2015). English L2 Reading. English L2 Reading (Third Edit). Routledge. https://doi.org/10.4324/97814106 14933. 
Musfiroh, T. M. (2005). Bercerita untuk Anak Usia Dini. Jakarta: Depdiknas.

Santrock, W. J. (2007). Perkembangan Anak. Alih bahasa: Mila Rahmawati dan Anna Kuswanti. Jakarta: Erlangga.
Suhartono. (2005). Pengembangan Ketrampilan Bicara Anak Usia Dini. Jakarta: Diknas.

Suyanto, K. (2005). English for Young Leaners. Jakarta: Bumi Aksara.

Tierney, R. J., \& Readence, J. E. (2005). Reading Strategies and Practices: A Compendium. Boston: Pearson. 